\title{
Doctors and compulsory procedures: Section 47 of the National Assistance Act 1948
}

\author{
D P FORSTER, P TIPLADY
}

There are several compulsory procedures which doctors may use in dealing with their patients. The best known is the Mental Health Act 1959 and information on its use is collected routinely and published annually. ${ }^{1}$ Regional health authorities can also supply information from their statistics departments. There have been many comments about the workings of the Act from those concerned with running the service and interested pressure groups. ${ }^{23}$ This dialogue, together with political interest in mental health, particularly compulsory admission to hospital, has led to a review of the Mental Health Act. ${ }^{4}$

In contrast, little information is available about other compulsory procedures, particularly the use of Section 47 of the National Assistance Act, 1948. This enables the "proper officer" (formerly the medical officer of health) to move a person from his home if it is thought to be in the interests of the patient or would prevent injury to the health of, or serious nuisance to, other people. Another registered medical practitioner, usually the general practitioner, also has to make the application.

The criteria for using this legislation are:

". . . a person in need of care and attention within the meaning of Section 47 of the National Assistance Act 1948, being a person who is:

*(a) suffering from grave chronic disease, namely... or, being aged, infirm or physically incapacitated, is living in insanitary conditions, and

(b) is unable to devote to himself (herself), and is not receiving from other persons, proper care and attention.

"Delete inapplicable terms."

The suitable accommodation need not be a hospital but the managers of the potential suitable accommodation must consent to the patient's going there. Under the original National Assistance Act of 1948 the application had to be made to the court and seven days notice given to the patient. The National Assistance (Amendment) Act 1951 enabled a similar procedure to be used in an emergency, whereby application could be made to a magistrate (rather than to the court itself) and the patient removed without delay. Recourse to the court is then necessary only if compulsory detention in the suitable accommodation is desired beyond three weeks, up to a period of three months. Nowadays it is almost invariably the 1951 Amendment of the National Assistance Act that is used.

\section{Methods and results}

We undertook a retrospective survey of the use of Section 47 by postal questionnaire in the Northern Regional Health Authority to cover the four-year period 1 January 1975 to 31 December 1978. Letters of introduction and explanation of the survey were sent to area medical officers and district community physicians. The questionnaire was divided into three: the first part was directed at actual removals by Section 47 during the reference period; the second asked for details of cases during

Department of Family and Community Medicine, University of Newcastle upon Tyne, Newcastle upon Tyne NE1 7RU

D P FORSTER, MSC, MRCPSYCH, senior lecturer in community medicine

Cumbria Health Authority, Carlisle CA1 1PT

$P$ TIPLADY, MB, MRCGP, specialist in community medicine the reference period in which a request was made for consideration of Section 47 but the section itself was not enacted; the final part sought the attitudes of community physicians to Section 47 legislation. The survey was carried out in May 1979 and reminder letters were sent out to non-responders five weeks later.

Each single-district area and each health district responded with data. In addition, each community physician concerned with Section 47 legislation gave an opinion on its use. Table I shows the age and sex of people removed under Section 47 in Northern RHA during the period 1975-8. Based on the 33

TABLE I-Age and sex of people removed under Section 47 (1951 Amendment), Northern RHA, 1975-8

\begin{tabular}{|c|c|c|c|c|}
\hline Age group & Men & Women & No & $\%$ \\
\hline $\begin{array}{c}<65 \\
65-74 \\
75-84 \\
85+ \\
\text { Not known (over 65) }\end{array}$ & $\begin{array}{l}1 \\
3 \\
1 \\
2 \\
1\end{array}$ & $\begin{array}{r}1 \\
3 \\
13 \\
7 \\
1\end{array}$ & $\begin{array}{r}2 \\
6 \\
14 \\
9 \\
2\end{array}$ & $\begin{array}{r}6 \cdot 1 \\
18 \cdot 2 \\
42 \cdot 4 \\
27 \cdot 3 \\
6 \cdot 1\end{array}$ \\
\hline Total No $\left({ }^{\circ}\right)$ & $.8(24 \cdot 2 \%)$ & $25(75 \cdot 8 \%)$ & 33 & $100 \cdot 1$ \\
\hline
\end{tabular}

One person (aged over 65) was admitted three times under Section 47 (1951 Amendment).

people removed, the annual all-ages incidence rate in Northern RHA was 2.6 per million all-ages population. The annual incidence rate for people aged 65 and over was $18 \cdot 1$ per million population aged 65 plus. The incidence rates for events were slightly in excess of these figures (2.8 and 19.3 respectively) since one patient over 65 was admitted three times during the survey period under Section 47. The male:female ratio was about $1: 3$.

Nineteen patients $(58 \%)$ were living alone at the time of removal and $31(89 \%)$ were removed from their own home. Table II shows the outcome at the date of the survey for patients removed under Section 47. There was no significant relation

TABLE II-Outcome of patients removed under Section 47 (1951 Amendment) by destination, Northern RHA, 1975-78

\begin{tabular}{|c|c|c|c|c|c|c|c|c|}
\hline \multirow{2}{*}{ Outcome } & \multicolumn{2}{|c|}{ Hospital } & \multicolumn{2}{|c|}{$\begin{array}{l}\text { Local authority } \\
\text { accommodation }\end{array}$} & \multicolumn{2}{|c|}{ Not known } & \multicolumn{2}{|c|}{ Total } \\
\hline & No & $\%$ & No & $\%$ & No & $\%$ & No & $\%$ \\
\hline $\begin{array}{l}\text { Dead } \\
\text { Alive } \\
\text { Not known }\end{array}$ & $\begin{array}{lr}. & 9 \\
\therefore & 6 \\
. & 10\end{array}$ & $\begin{array}{l}36 \cdot 0 \\
24 \cdot 0 \\
40 \cdot 0\end{array}$ & $\begin{array}{l}4 \\
1 \\
2\end{array}$ & $\begin{array}{l}57 \cdot 1 \\
14 \cdot 3 \\
28 \cdot 6\end{array}$ & $\begin{array}{l}0 \\
0 \\
1\end{array}$ & $\begin{array}{r}0 \\
0 \\
100 \cdot 0\end{array}$ & $\begin{array}{r}13 \\
7 \\
13\end{array}$ & $\begin{array}{l}39 \cdot 4 \\
21 \cdot 2 \\
39 \cdot 4\end{array}$ \\
\hline Total & .. 25 & $100 \cdot 0$ & 7 & $100 \cdot 0$ & 1 & $100 \cdot 0$ & 33 & $100 \cdot 0$ \\
\hline
\end{tabular}

between outcome and the accommodation to which the patient was moved. Further analysis of the deaths showed that $36 \%$ occurred within four weeks of removal and $91 \%$ within one year of removal. Only five patients $(15 \%)$ returned to their own original residence and in only four cases $(11 \%)$ was application made to the court for detention of the patient beyond three weeks. The ratio of requests for Section 47 to enactments was $6 \cdot 7: 1$.

Table III shows the opinions of community physicians. 
TABLE III-Opinions of community physicians, Northern RHA

\begin{tabular}{|c|c|c|c|c|}
\hline \multirow[b]{2}{*}{ Opinion } & \multicolumn{4}{|c|}{ Infringement of human rights } \\
\hline & Yes & No & Notal & $\%$ \\
\hline $\begin{array}{c}\text { Repeal of Section } 47 \text { legislation } \\
\text { immediately } \ldots\end{array}$ & 3 & 0 & 3 & $15 \cdot 0$ \\
\hline $\begin{array}{l}\text { Regular statistical returns on } \\
\text { use of Section } 47 \text {. }\end{array}$ & 1 & 1 & 2 & $10 \cdot 0$ \\
\hline $\begin{array}{l}\text { confidential inquiry into each } \\
\text { Section } 47 \text { admission. } \\
\text { Other (Use Mental Health Act) }\end{array}$ & $\begin{array}{l}2 \\
1\end{array}$ & $\begin{array}{l}2 \\
0\end{array}$ & $\begin{array}{l}4 \\
1\end{array}$ & $\begin{array}{r}20 \cdot 0 \\
5 \cdot 0\end{array}$ \\
\hline $\begin{array}{cccc}\text { No change in Section } 47 & \text { pro- } \\
\text { cedures } & . . & . & .\end{array}$ & 2 & 8 & 10 & $50 \cdot 0$ \\
\hline Total No $(\%) \quad \ldots$ & $9(45 \%)$ & $11(55 \%)$ & 20 & 100 \\
\hline
\end{tabular}

\section{Discussion}

Is the incidence of use of Section 47 rising or falling ? Our survey provides tentative evidence that it is falling since an annual incidence rate for events of 2.8 per million all ages population has been found compared with an incidence rate of 7.7 per million in an unpublished DHSS survey on a national sample in the late ' $60 \mathrm{~s}$. The comparison is approximate since the samples and the case-finding techniques differed. We have no reason to believe, however, that the population at risk in Northern RHA is intrinsically less vulnerable to Section 47 than a sample drawn from England as a whole. This decrease reflects the fall in the use of compulsory legislation under the Mental Health Act. For example, the number of compulsory admissions to mental illness and mental handicap units in England and Wales decreased from $35123(16.5 \%$ of all admissions) in 1966 to 22957 (9.2\% of all admissions) in 1976.4 Muir Gray has drawn attention to the possibility that elderly patients may be persuaded to leave their homes without the use of compulsory legislation but in a manner which could be described as "not entirely voluntary." Many of these cases, he believes, may not have been reported to the community physician. ${ }^{5}$ We recognise that possibly this type of "not entirely voluntary" admission may have increased simultaneously with the fall in the incidence of use of Section 47.

Our study has shown that a high proportion of patients die fairly soon after removal and the chances of a patient returning to his own original residence are small. On objective criteria, therefore, Section 47 seems to have been of little benefit. But we have not been able to evaluate the relief of pain or other forms of suffering which may have resulted from use of Section 47.

No information is collected routinely by RHAs or the DHSS about the use of Section 47. Though half the community physicians suggested no change in the Act, we think that there should be some monitoring of its use, with central collection of data and, since the incidence of use is now low, a confidential inquiry into each case. Only in this way will it be possible to elucidate the critical factors which lead to the need for the admission powers of Section 47. The functions of community services in preventing-or more particularly failing to preventa compulsory removal would become apparent. This is particularly important in services facing public expenditure cuts.

We are grateful to the community physicians who contributed data to this survey and the preceding pilot study; to the DHSS for permission to use data from its unpublished national survey; and to Miss Dawn Turnbull and Mrs Patricia Bullock for secretarial help.

\section{References}

${ }^{1}$ Department of Health and Social Security. Psychiatric hospitals and units in England. Inpatient statistics from the Mental Health Inquiry, Statistical and Research Report Series. London: HMSO.

2 Rollin HR. Social and legal repercussions of the Mental Health Act, 1959. Br Med F 1963; :786-8.

3 Gostin LO. A human condition: The Mental Health Act from 1959 to 1975, observations, analysis and proposals for reform. London: National Association for Mental Health, 1975.

4 Department of Health and Social Security, Home Office, Welsh Office, Lord Chancellor's Department. Review of the Mental Health Act, 1959, Cmnd 7320. London: HMSO, 1978.

- Muir Gray JA. An infringement of liberty. CHC News 1979;45:2.

(Accepted 22 Fanuary 1980) accurate information as a result of much hard work by individuals, once again in their spare time. The foundation seems to be that resources in the NHS are correctly allocated on a specialty basis. This is unlikely. Up to now expansion of services and improvements in treatment have been largely dependent on the interests, energy, and political skill of individuals or small groups rather than the intrinsic value of their proposals. Nettle grasping has been noticeably rare in the diffuse structure which appears to make decisions in the Health Service. At present "clinical freedom" is used as a rallying cry to prevent the scrutiny of resource consumption by the successful activists.

The basis on which regional and national strategies are advanced must be the factual evidence of needs that could be met. Priorities of need have to be decided by the democratically elected government in consultation with the medical profession. The public-the "consumers"-must be consulted. Clinical freedom should act only within the framework of these priority decisions. Health care planning teams should identify the real level of services and needs in their area. District management teams close to the people who are treating patients must then decide on how best to evolve their pattern of care.

Cost limits make these decisions more difficult and the present financial constraints must lead to a severe reduction in services. If, however, this is temporary and forces a genuine examination of priorities the ultimate development of the NHS may benefit.
I would like to thank Dr H Middleton, Dr S A Mason, Dr R Seed, and $\mathrm{Dr} \mathrm{J}$ Wedley for their help in the design of the study; all district representatives for their contributions; and Mrs $\mathrm{H}$ Hancock for secretarial services.

\section{References}

1 Department of Health and Social Security. Sharing resources for health in England, Report of the Resource Allocation Working Party. London: HMSO, 1976.

2 South-east Thames Regional Health Authority. Consultant manpower planning guidelines. London: South-east Thames RHA, 1978.

3 Association of Anaesthetists. Work load for consultant anaesthetists under the existing contract. London: Association of Anaesthetists, 1975.

4 Association of Anaesthetists. Report of a working party on manpower and staffing. London: Association of Anaesthetists, 1978.

5 Doran FSA. Medical manpower and hospital staffing. $\mathrm{Br}$ Med $\mathcal{F} 1976$;ii: 531.

${ }^{6}$ Maynard A, Walker A. Doctor manpower 1975-2000: alternative forecasts and their resource implications. London: HMSO, 1978.

7 Seed RF. How much is Jack worth ? A study of the work of anaesthetists in the SE Thames Region. Anaesthesia, 1978;33:49-53.

8 Royal College of Surgeons of England. Assessment of content of consultant posts. Annals of the Royal College of Surgeons of England 1979;61:165.

9 Selwyn Crawford J, Opit LJ. A survey of the anaesthetic service to obsettrics in the Birmingham region. London: Association of Anaesthetists, 1975.

(Accepted 4 February 1980)

Published by the Proprietors, THE BRITISH MEDICAL ASSOCIATION, Tavistock Square, London WC1H 9JR, and printed in Great Britain by George Pulman and Sons Limited of London and Bletchley, Typesetting by Bedford Typesetters Limited, Bedford, and TypeMatters (London) Ltd., London E.C.1. Registered as a Newspaper 